\title{
Etherification of Glycerol with Benzyl Alcohol Catalyzed by Solid Acids
}

\author{
Camila R. B. da Silva, Válter L. C. Gonçalves, Elizabeth R. Lachter and Claudio J. A. Mota* \\ Instituto de Química, Universidade Federal do Rio de Janeiro, Cidade Universitária, \\ Av. Athos da Silveira Ramos 149, CT Bloco A, 21941-909 Rio de Janeiro-RJ, Brazil
}

\begin{abstract}
Neste trabalho apresentamos os resultados da eterificação do glicerol com álcool benzílico, catalisada por diferentes sólidos ácidos. O mono-éter benzílico do glicerol foi o produto principal nas reações com a zeólita $\beta$ e a resina ácida Amberlyst-35. Já o éter-di-benzílico foi o produto majoritário nas reações com o ácido p-tolueno-sulfônico e a argila K-10 como catalisadores. O ácido nióbico foi inativo na reação. A estrutura porosa da zeólita impediu a formação significativa de produtos de di e tri eterificação.
\end{abstract}

In this work we present the results of glycerol etherification with benzyl alcohol, catalyzed by different solid acids. The mono-benzyl-glycerol ether was the main product in the reactions catalyzed by $\beta$ zeolite and Amberlyst-35 acid resin, whereas di-benzyl-ether was formed in higher yield with the use of p-toluene-sulfonic acid and K-10 montmorillonite as catalyst. Niobic acid was inactive in this reaction. The porous structure of the zeolite impaired the formation of di and tri-benzyl-glycerol ethers.

Keywords: glycerol, solid acids, etherification

\section{Introduction}

The concern about global warming, due to the use of fossil fuels, has motivated the debate about biofuels, produced from biomass materials. Among them, biodiesel appears as one of the most promising and is normally produced through the transesterification of vegetable oils or animal fat with methanol. ${ }^{1}$ This reaction is usually carried out under alkaline catalysis conditions, affording methyl esters of fatty acids, the biodiesel themselves, and glycerol.

One of the most important challenges of the biodiesel production is the destination of the glycerol formed. According to recent projections, ${ }^{2}$ the world glycerol production would reach 1.2 million tons in 2010, due to the increasing use of biodiesel. This forecast affects the price of glycerol and of the biodiesel as well, because the producers have to find a destination for the glycerol.

The main use of glycerol is in personal care and cosmetics, but its use as a valuable feedstock for new products and processes is growing in importance; some reviews about it have appeared in the literature..$^{2-4}$ The catalytic hydrogenation of glycerol to 1,2 and

*e-mail: cmota@iq.ufrj.br 1,3-propanediol ${ }^{5-7}$ might become an industrial process in a near future, as some major chemical companies announced ${ }^{8}$ the interest in building commercial plants of this process. Glycerol reforming to syn gas $^{9}$ is also a potential economic process, which might be coupled with Fischer-Tropsch type catalysts, ${ }^{10}$ to yield gasoline range hydrocarbons. Yet, glycerol might be blended with vacuum gasoil for processing in catalytic cracking units. ${ }^{11}$

Many of the previous applications may require further developments or might be restricted to some particular conditions of the glycerol supply. Therefore, the search for other applications, especially involving less time demanding technologies, is still needed.

Glycerol ethers have many potential uses, such as fuel additives, ${ }^{12}$ solvents, ${ }^{13}$ cryogenics, ${ }^{14}$ and anti-bacterial agents. ${ }^{15}$ Reactions of glycerol with isobutene ${ }^{16}$ or tertbutano $1{ }^{17}$ under acid catalysis conditions afford tert-butylglycerol ethers, which have potential for blending with diesel. ${ }^{18}$ Recently, Gu et al. ${ }^{19}$ reported the etherification of glycerol with different alcohols catalyzed by acidfunctionalized silica. They reported yields varying from 61 to $96 \%$ of the mono and di glycerol ethers, using batch reaction conditions. These results prompted us to report some preliminary data of glycerol benzylation with benzyl alcohol, using different types of heterogeneous 
<smiles>OCC(O)COCc1ccccc1COCC(O)COCc1ccccc1COCC(O)COCc1ccccc1</smiles>

Scheme 1. Etherification of glycerol with benzyl alcohol in the presence of acid catalysts.

acid catalysts, aiming to produce mono, di and tri benzyl glycerol ethers (Scheme 1).

\section{Experimental}

Reactions were carried out in batch mode, using $5.0 \mathrm{~g}$ (54 mmol) of glycerol, $17.5 \mathrm{~g}(162 \mathrm{mmol})$ of benzyl alcohol and $0.5 \mathrm{~g}$ of the pre-treated catalyst. The system was kept at a controlled temperature and continuously purged with nitrogen, to carry away the water molecules formed in the reaction. The products were analyzed by gas chromatography and, in some cases, by gas chromatography coupled to a mass spectrometer.

The catalysts used were Amberlyst 35 (Rohm and Haas), zeolite $\beta$ (Zeolyst), K-10 montmorillonite (Fluka), niobic acid (CBMM) as well as p-toluene-sulfonic acid (PTSA) for comparison with a homogeneous system. Table 1 shows the pre-treatment conditions and Table 2 reports characterization and acidity data of the heterogeneous catalysts.

Table 1. Pre-treatment conditions of the heterogeneous catalysts

\begin{tabular}{lcc}
\hline Catalyst & $\begin{array}{c}\text { Pre-treatment } \\
\text { Temperature } /\left({ }^{\circ} \mathrm{C}\right)\end{array}$ & time/conditions \\
\hline Amberlyst-35 & $105\left(10^{\circ} \mathrm{C} \mathrm{min}{ }^{-1}\right)$ & Overnight/vacuum \\
Zeolite $\beta$ & $400\left(10^{\circ} \mathrm{C} \mathrm{min}^{-1}\right)$ & One hour \\
Niobic Acid & $\left.300\left(5^{\circ} \mathrm{C} \mathrm{min}\right)^{-1}\right)$ & Three hours \\
K-10 & $110\left(10^{\circ} \mathrm{C} \mathrm{min}^{-1}\right)$ & One hour \\
\hline
\end{tabular}

Table 2. Surface areas and acidity of the catalysts

\begin{tabular}{lccc}
\hline Catalyst & $\begin{array}{c}\text { Área/ } \\
\left(\mathrm{m}^{2} \mathrm{~g}^{-1}\right)\end{array}$ & Si/Al & $\begin{array}{c}\text { Acidity }{ }^{\mathrm{a}} / \\
\left(\mathrm{mmol} \mathrm{n} \text {-butilamine } \mathrm{g}^{-1}\right)\end{array}$ \\
\hline Amberlyst-35 & 50 & - & $5.2^{\mathrm{b}}$ \\
K-10 & 240 & 6.6 & 0.5 \\
Niobic Acid & 187 & - & 0.3 \\
H- $\beta$ Zeolite & 633 & 16 & 1.6 \\
\hline
\end{tabular}

${ }^{\mathrm{a}}$ Measured $^{21}$ by n-butylamine adsorption at $150{ }^{\circ} \mathrm{C}$; ${ }^{\text {b Informed by the }}$ producer.

\section{Results and Discussion}

Figure 1 shows the product distribution of the acidcatalyzed reaction between glycerol and benzyl alcohol at $110^{\circ} \mathrm{C}$ and $120 \mathrm{~min}$ of reaction time. One can see that PTSA and K-10 montmorillonite favors the formation of di-benzyl ether, arisen from the self-etherification of benzyl alcohol, relative to the benzyl-glycerol ethers. The yield of the mono-benzyl-glycerol ether was higher over the K-10 catalyst compared with PTSA. Self-etherification of benzyl alcohol may be explained by the 3:1 molar ratio of benzyl alcohol to glycerol used in this study, whereas Gu et al. ${ }^{19}$ used a ratio of 1:1 and apparently did not find self-etherification. Except for the niobic acid, all reactions showed $100 \%$ glycerol conversion.

Amberlyst-35 and zeolite $\beta$ showed a superior performance than the other catalysts, producing the glycerol benzyl ethers in higher yield than the di-benzyl 
ether. The zeolite showed the best selectivity to the monobenzyl-glycerol ether among the catalysts tested. In fact, the selectivity to the di and tri-benzyl-glycerol ethers was very low over the zeolite catalyst. This might be associated with the shape selectivity property ${ }^{20}$ of zeolites, which impairs the formation of bulk transition states. Thus, the pore structure of zeolite $\beta$ may not accommodate the transition state for a second or third benzylation of glycerol. Therefore, zeolite $\beta$ might be used as a good catalyst to produce the mono-benzyl-glycerol ether, with little or no formation of the di and tri-benzyl ethers.

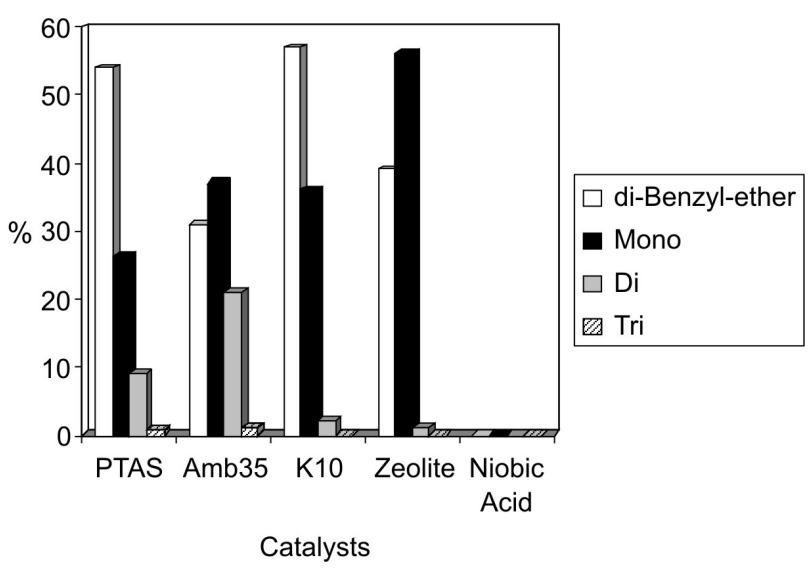

Figure 1. Yield of products formed on the reaction of glycerol with benzyl alcohol at $110{ }^{\circ} \mathrm{C}$ and $120 \mathrm{~min}$. Mono, Di and Tri stands for the benzyl-glycerol ethers.

Niobic acid was practically inactive toward the reaction, even at longer reaction times. This might be associated with its lower acidity, compared to the other catalyst tested, not only related with respect to total acidity, but also to the acid strength. We have recently published ${ }^{21}$ a study on the use of linear free energy relationship to estimate the acid strength of different solid acids and Niobic acid was the weakest solid acid material tested, in agreement with its poor catalytic activity. On the other hand, Amberlyst-35 and zeolite $\beta$ presented the highest acidity among the catalyst tested and were more selective toward the formation of the benzyl-glycerol ethers. This might suggest that acidity plays an important role in the reaction.

A surprising fact was the high activity of K-10 montmorillonite. Despite of this catalyst does not present a high acidity, it produced the benzyl-glycerol ethers in good yield, although di-benzyl ether was the main product. In studies ${ }^{22}$ of glycerol acetylation with acetic acid this catalyst presented high activity as well, comparable to the activity of an acid exchange resin. It is not completely clear why $\mathrm{K}-10$ montmorillonite performs well in these reactions, but a possible explanation is that its structure would be capable of adsorbing the water formed, probably shifting the equilibrium or preventing catalyst deactivation.

In the benzylation of anisole with benzyl alcohol catalyzed by clays, ${ }^{23}$ ion exchange resins ${ }^{24}$ and alumina ${ }^{25}$ the dibenzyl-ether was also observed, together with the alkylation product. Deshpande et al. ${ }^{26}$ reported that etherification is faster than alkylation over K-10 modified with $\mathrm{SbCl}_{3}$ and that ether formation can be associated to both, Brønsted and Lewis acid sites. This might explain the selectivity pattern for K-10, Amberlyst-35 and zeolite $\beta$, as the last two catalysts have mostly Brønsted acidity, whereas K-10 normally present significant concentration of Lewis acid sites.

\section{Conclusions}

The etherification of glycerol with benzyl alcohol can be achieved with the use of heterogeneous acid catalysts. In all cases, self-etherification of benzyl alcohol was also observed. Over zeolite $\beta$ and Amberlyst-35 the monobenzyl-glycerol ether was the main product formed, whereas over K-10 montmorillonite and PTSA the dibenzyl ether was formed in higher yield than the glycerol benzyl ethers. Niobic acid was inactive toward the reaction. Zeolite $\beta$ was the best catalyst for the production of the mono benzyl-glycerol ether, probably due to its shape selective properties, that impairs the formation of the other bulkier ether derivatives.

\section{Acknowledgments}

Authors thank FINEP, CNPq and FAPERJ for financial support.

\section{References}

1. Pinto, A C.; Guarieiro, L. N.; Resende, M. J. C.; Ribeiro N. M.; Torres, E. A; Lopes, W. A.; Pereira, P. A D.; De Andrade J. B.; J. Braz. Chem. Soc. 2005, 16, 1313.

2. Zhou, C. H.; Beltramini, J. N.; Fan, Y. X.; Lu, G. Q.; Chem. Soc. Rev. 2008, 37, 527.

3. Behr, A.; Eilting, J.; Irawadi, K.; Leschinski, J.; Lindner, F.; Green Chem. 2008, 10, 13.

4. Pagliaro, M.; Ciriminna, R.; Kimura, H.; Rossi, M.; DeLLa Pina C.; Angew. Chem. Inter. Ed. 2007, 46, 4434.

5. Dasari, M. A.; Kiatsimkul, P. P.; Sutterlin,W. R.; Suppes, G. J.; Appl. Catal. A 2005, 281, 225.

6. Kusunoki, Y.; Miyazawa, T.; Kunimori, K.; Tomishige, K.; Catal. Commun. 2005, 6, 645.

7. Miyazawa, T.; Kusunoki, Y; Kunimori, K.; Tomishige, K.; J. Catal. 2006, 240, 213. 
8. McCoy, M.; Chem. Eng. News 2007, 85, 9.

9. Soares, R. R.; Simonetti, D. A.; Dumesic, J. A.; Angew. Chem. Int. Ed. 2006, 45, 3982.

10. Simonetti, D. A.; Rass-Hansen, J.; Kunkes, E. L.; Soares, R. R.; Dumesic, J. A.; Green Chem. 2007, 9, 1073.

11. Corma, A.; Huber, G. W.; Sauvanaud, L.; O`Connor, P.; J. Catal. 2007, 247, 307.

12. Mota, C. J. A.; Gonçalves, V. L. C.; Brazilian Patent PI 0700063-4, 2007

13. Queste, S.; Bauduin, P.; Touraud, D.; Kunz, W.; Aubry, J. M.; Green Chem. 2006, 8, 822.

14. Koshchii, S. V.; Russ. J. Appl. Chem. 2002, 75, 1434.

15. Haynes, M. P.; Buckley, H. R.; Higgins, M. L.; Pieringer, R. A.; Antimicrob. Agents Chemother. 1994, 38, 1523.

16. Karinen, R. S.; Krause, A. O. I.; Appl. Catal. A 2003, 306, 128.

17. Klepacova, K.; Mravec, D.; Bajus, M.; Appl. Catal. A 2005, 294,141.

18. Wessendorf, R.; Erdoel \& Kohle Erdgas Petrochemie 1995, 48, 138.
19. Gu, Y.; Azzouzi, A.; Pouilloux, Y.; Jerome, F.; Barrault, J.; Green Chem. 2008, 10, 164.

20. Smit, B.; Maessen, T. L. M.; Nature 2008, 451, 671.

21. Gonçalves, V. L. C.; Rodrigues, R. C.; Lorençatto, R.; Mota, C. J. A.; J. Catal. 2007, 248, 158.

22. Gonçalves, V. L. C.; Pinto, B. P.; Silva, J. C.; Mota, C. J. A.; Catal. Today 2008, 133, 673.

23. Yadav, G. D.; Thorat T.S.; Khumbar, P. S.; Tetrahedron Lett. 1993, 34, 529.

24. da Silva, M. S. M.; da Costa, C. L.; Pinto, M. M.; Lachter, E. R.; React. Funct. Polym. 1995, 25, 55.

25. de la Cruz, M. H.C.; Abdel-Rehim, M. A.; Rocha, A. S.; da Silva, J. F.C.; Faro Jr., A. C.; Lachter, E. R.; Catal. Comm. 2007, 8,1650 .

26. Deshpande, A.B.; Bajpai, A.R.; Samant, S.D. ; Appl. Catal., A. 2001, 209, 229.

Received: July 29, 2008

Web Release Date: December 18, 2008 